\title{
UPAYA MENINGKATKAN MOTIVASI DAN HASIL BELAJAR IPA MATERI KLASIFIKASI MAKHLUK HIDUP MELALUI PENERAPAN MODEL PEMBELAJARAN INKUIRI TERBIMBING (GUIDED INQUIRI) PADA SISWA KELAS VII A MTS NEGERI BATANG
}

\author{
Nani Nursani \\ MTs Negeri Batang \\ naninursanibatang@gmail.com
}

DOI : http://doi.org/10.37730/edutrained.v5i`1.110

Diterima: 27 Oktober 2020 | Disetujui: 22 Juni 2021 | Dipublikasikan: 6 Juli 2021

\begin{abstract}
Abstrak
Penelitian dengan judul Upaya Meningkatkan Motivasi dan Hasil Belajar IPA Materi Klasifikasi Makhluk Hidup Melalui Penerapan Model Pembelajaran Inkuiri Terbimbing (Guided Inquiri) Pada Siswa Kelas VII A MTs Negeri Batang, adalah Penelitian Tindakan Kelas. Tujuan penelitian ini adalah menerapkan model pembelajaran Inquiri Terbimbing (Guided Inquiri), sehingga dapat peningkatan motivasi belajar dan hasil belajar siswa. Penelitan tindakan kelas ini dilaksanakan dengan 2 siklus, setiap siklus terdiri dari 3 pertemuan Penelitian ini menunjukkan bahwa motivasi peserta didik dari kondisi awal, siklus 1 dan siklus 2 terus mengalami peningkatan. Persentase hasil belajar peserta didik yang tuntas dan melampaui KKM (dari 50\% menjadi 91,67\%). Indikator keberhasilan PTK ini adalah, jika persentase peserta didik yang nilai belajarnya sudah tuntas mencapai minimal 80\%. maka PTK sudah berhasil. Kesimpulan PTK ini adalah motivasi dan hasil belajar peserta didik mengalami peningkatan setelah diterapkan pembelajaran melalui model pembelajaran Inkuiri Terbimbing (Guided Inquiri).
\end{abstract}

Kata Kunci: motivasi belajar, hasil belajar, Inkuiri Terbimbing

\begin{abstract}
The research entitled Efforts to increase Motivation and Science Learning Outcomes for Classification of Living Things Through the Application of Guided Inquiry Learning Models for Class VII A MTs Negeri Batang, is Classroom Action Research. The purpose of this research is to apply the Guided Inquiry learning model, so that it can increase students' learning motivation and learning outcomes. This classroom action research was carried out in 2 cycles, each cycle consisting of 3 meetings. This research showed that the motivation of students from the initial conditions, cycle 1 and cycle 2 continued to increase. Percentage of student learning outcomes who complete and exceed the KKM (from 50\% to 91.67\%). The indicator of the success of this Classroom Action Research is, if the percentage of students whose learning scores have reached a minimum of $80 \%$. then it has been successful. The conclusion of this Classroom Action Research is that students' motivation and learning outcomes have increased after learning is applied through the Guided Inquiry learning model.
\end{abstract}

Keywords: learning motivation, learning outcomes, Guided Inquiry 


\section{PENDAHULUAN}

Motivasi belajar sangat berpengaruh terhadap hasil belajar. Ketika motivasi belajar siswa rendah maka semakin rendah pula hasil berlajar siswa. Sebaliknya apabila motivasi belajar siswa tinggi maka hasil belajar siswa juga tinggi.

Berdasarkan hasil observasi awal dalam pembelajaran Ilmu Pengetahuan Alam (IPA) di Madrasah Tsanawiyah Negeri Batang (MTsN Batang) pada semester gasal tahun pelajaran 2019/2020, hasil belajar peserta didik kelas VII belum mencapai hasil sesuai harapan. Berdasarkan hasil analisis ulangan harian, $43,25 \%$ peserta didik yang tuntas KKM 72 dan 66,25\% peserta didik belum tuntas KKM (Kriteria Ketuntasan Minimal).

Harapan dari pembelajaran yang dilakukan adalah hasil belajar peserta didik dalam mapel IPA 100\% mencapai nilai diatas KKM 72 atau setidaknya peserta didik mencapai nilai sama dengan KKM.

Aktivitas peserta didik selama proses pembelajaran diharapkan menumbuhkan kreatifitas dan inovatif peserta didik dalam pembelajaran IPA. Materi IPA terutama biologi berisi nama nama ilmiah yang sebaiknya dihafalkan, ternyata siswa mengalami kesulitan dalam mempelajarinya. Penyebab lain adalah kurangnya kreativitas guru dalam memotivasi peserta didik untuk memahami materi IPA. Guru sering memberikan tugas membaca dan menghafal kepada peserta didik, dan kurang memberikan motivasi serta berinovasi dengan menggunakan metode, media atau alat peraga yang variatif dalam proses pembelajaran.

Materi Klasifikasi Makhluk Hidup dalam mapel IPA merupakan materi yang cukup banyak yang harus dikuasai peserta didik. Pada saat pembelajaran peran peserta didik hanya mendengar dan mencatat materi yang disampaikan guru, sehingga peserta didik kurang bersemangat dan tidak memperhatikan guru saat menjelaskan. Meskipun sudah ada percobaan sederhana, tapi tetap tidak membuat motivasi belajar peserta didik meningkat. Hal tersebut disebabkan dalam pembelajaran IPA sering hanya diberi definisi suatu kata dan hanya diberikan prinsip dan konsep pembelajaran tanpa adanya proses ilmiah untuk menemukan konsep.

Berdasarkan analisis penyebab masalah, langkah yang diduga dapat meningkatkan motivasi dan hasil belajar peserta didik dalam materi klasifikasi makhluk hidup adalah dengan menerapkan model pembelajaran Inkuiri terbimbing. Pembelajaran Inkuiri merupakan suatu rangkaian belajar yang melibatkan secara maksimal seluruh kemampuan peserta didik untuk mencari dan menyelidiki secara sistematis, kritis, logis, analitis, sehingga mereka dapat merumuskan sendiri penemuannya dengan penuh percaya diri.

Menurut Trianto (2009:166) model pembelajaran inkuiri terbimbing (guided inquiry) ini peserta didik lebih banyak aktif dalam proses pembelajarannya yang telah dikondisikan untuk dapat menerapkan berpikir dalam upaya menggali sendiri segala konsep untuk mengambil inisiatif dalam usaha memecahkan masalah, mengambil keputusan, dan melatih berpikir kitis peserta didik. Sehingga model pembelajaran inkuiri ini diharapkan dapat meningkatkan motivasi dan hasil belajar peserta didik.

Rumusan masalah dari Penelitian Tindakan kelas ini adalah 1) Bagaimana proses pembelajaran dengan menggunakan model Pembelajaran Inquiri Terbimbing dapat meningkatkan motivasi dan hasil belajar IPA materi Klasifikasi Makhluk hidup pada peserta didik kelas VII A MTs N Batang semester gasal tahun pelajaran 2019/2020; 2) Apakah dengan penerapan Model Pembelajaran Inquiri Terbimbing dapat meningkatkan motivasi belajar IPA materi Klasifikasi Makhluk hidup pada peserta didik kelas VII A MTs N Batang semester gasal tahun pelajaran 2019/2020; 3) Apakah dengan penerapan Model pembelajaran Inquiri 
Terbimbing dapat meningkatkan hasil belajar IPA materi Klasifikasi Makhluk Hidup pada peserta didik kelas VII A MTsN Batang semester gasal tahun pelajaran 2019/2020.

Tujuan Penelitian Tindakan Kelas ini dilakukan adalah 1) Mengetahui proses pembelajaran dengan menggunakan model Pembelajaran Inquiri Terbimbing untuk meningkatkan motivasi dan hasil belajar IPA materi Klasifikasi Makhluk Hidup pada peserta didik kelas VIIA MTs $\mathrm{N}$ Batang semester gasal tahun pelajaran 2019/2020; 2) Mengetahui seberapa besar motivasi belajar peserta didik setelah diterapkannya model Pembelajaran Inquiri Terbimbing dalam materi Klasifikasi Makhluk Hidup pada peserta didik kelas VIIA MTs N Batang semester gasal tahun pelajaran 2019/2020; 3) Mengetahui hasil belajar peserta didik setelah diterapkannya model Pembelajaran Inkuiri Terbimbing dalam materi Klasifikasi Makhluk Hidup pada peserta didik kelas VIIA MTs N Batang semester gasal tahun pelajaran 2019/2020.

Berdasarkan masalah penelitian dan tujuan penelitian yang dikemukakan di atas, hasil penelitian ini diharapkan mempunyai manfaat sebagai berikut 1) Bagi madrasah, hasil penelitian ini diharapkan mampu menambah informasi tentang model-model pembelajaran ; 2) Bagi guru hasil penelitian ini digunakan sebagai alternatif dalam pembelajaran IPA dan meningkatkan profesionalisme guru; 3) Bagi peserta didik hasil penelitian ini dapat digunakan untuk membantu meningkatkan motivasi belajar dan membantu memahami konsep materi sehingga hasil belajar peserta didik pada mapel IPA meningkat; 4) Bagi peneliti hasil penelitian ini dapat meningkatkan motivasi dan hasil belajar peserta didik.

\section{KAJIAN PUSTAKA}

\section{Motivasi Belajar}

Dalam Kamus Besar Bahasa Indonesia, (Depdikbud, 1996:593) motivasi didefinisikan sebagai dorongan yang timbul pada diri seseorang sadar atau tidak sadar untuk melakukan suatu tindakan dengan tujuan tertentu. W.S Winkel (1996:53) mengatakan, bahwa belajar adalah suatu aktivitas mental/psikis yang berlangsung dalam interaksi aktif dengan lingkungannya, yang menghasilkan perubahanperubahan, pengetahuan, pemahaman, keterampilan dan nilai sikap, serta perubahan itu bersifat secara relatif konstan dan tetap. Sedangkan yang dimaksud motivasi belajar adalah keinginan yang mengaktifkan, menggerakkan, menyalurkan dan mengarahkan sikap dan perilaku individu untuk belajar. Menurut Sardiman (2011), motivasi belajar adalah keseluruhan daya penggerak dalam diri peserta didik yang menimbulkan kegiatan belajar, yang menjamin kelangsungan dari kegiatan belajar dan memberikan arah pada kegiatan belajar, sehingga tujuan yang dikehendaki oleh subyek belajar itu dapat tercapai.

\section{Hasil Belajar}

Mulyana (2003), menyatakan bahwa hasil belajar adalah kemampuan yang diperoleh anak setelah melakukan kegiatan belajar mengajar. Belajar itu sendiri merupakan suatu proses dari seseorang yang berusaha untuk memperolah suatu bentuk perubahan perilaku yang relatif menetap. Anak yang berhasil belajar ialah anak yang berhasil mencapai tujuan pembelajaran yang ditetapkan oleh guru.

Hasil belajar peserta didik meliputi pengetahuan dan kemampuan yang dimiliki peserta didik setelah menerima pengalaman belajar, baik hasil tes tertulis, tes lisan, sikap dan perbuatan (Sudjana, 2004). Lebih lanjut (Kingsley dalam Sudjana, 2004) mengungkapkan hasi belajar mengajar merupakan keterampilan, kebiasaan, pengetahuan, pengarahan, sikap dan cita-cita. Menurut Bloom dalam Sanjaya (2008), hasil belajar meliputi tiga domain: domain kognitif (pemahaman) yakni tujuan pendidikan yang berhubungan dengan kemampuan berfikir seperti mengingat 
dan memecahkan masalah, Domain afektif adalah (sikap dan prilaku) yakni berkenaan dengan sikap, nilai-nilai dan apresiasi. Domain psikomotor yakni berhubungan dengan kemampuan keterampilan atau skill seseorang.

Hasil belajar adalah kemampuan yang dimiliki peserta didik setelah melakukan serangkaian proses belajar sehingga mampu mencapai hasil sesuai yang diharapkan

\section{Inkuiri Terbimbing}

Menurut Trianto (2009:166) model pembelajaran inkuiri terbimbing (guided inquiry) ini peserta didik lebih banyak aktif dalam proses pembelajarannya yang telah dikondisikan untuk dapat menerapkan berpikir dalam upaya menggali sendiri segala konsep untuk mengambil inisiatif dalam usaha memecahkan masalah, mengambil keputusan, dan melatih berpikir kitis peserta didik Model pembelajaran inkuri terbimbing merupakan salah satu cara untuk mengembangkan keterampilan berpikir kritis dalam pembelajaran. Dalam pembelajaran ini guru bertindak selaku organisator dan fasilitator, guru tidak memberitahukan konsep-konsep tetapi membimbing peserta didik menemukan konsep-konsep tersebut dengan melalui kegiatan belajar. Sehingga konsep yang didapat berdasarkan kegiatan dan pengalaman belajar tersebut akan selalu diingat peserta didik dalam waktu yang lama.

Tabel 1. Sintaks Inkuiri Terbimbing

\begin{tabular}{|c|c|}
\hline Langkah & Deskripsi \\
\hline $\begin{array}{l}\text { Stimulation } \\
\text { (Pemberian } \\
\text { rangsangan) }\end{array}$ & $\begin{array}{l}\text { Merumuskan } \\
\text { pertanyaan, masalah } \\
\text { atau topik yang akan } \\
\text { diselidiki }\end{array}$ \\
\hline $\begin{array}{l}\text { Problem } \\
\text { statement } \\
\text { (Pernyataan/ } \\
\text { identifikasi } \\
\text { masalah) }\end{array}$ & $\begin{array}{l}\text { Mengidentifikasi } \\
\text { masalah dan } \\
\text { dirumuskan dalam } \\
\text { bentuk hipotesis }\end{array}$ \\
\hline $\begin{array}{l}\text { Data collection ( } \\
\text { Pengumpulan } \\
\text { data) }\end{array}$ & $\begin{array}{l}\text { Mengumpukan } \\
\text { informasi untuk } \\
\text { membuktikan } \\
\text { hipotesis }\end{array}$ \\
\hline
\end{tabular}

\begin{tabular}{l|l}
\hline $\begin{array}{l}\text { Data processing } \\
\text { (Pengolahan } \\
\text { data) }\end{array}$ & $\begin{array}{l}\text { Mengolah data dan } \\
\text { informasi dengan } \\
\text { analisis data }\end{array}$ \\
\hline $\begin{array}{l}\text { Verification ( } \\
\text { Pembuktian) }\end{array}$ & $\begin{array}{l}\text { Melakukan } \\
\text { pemeriksaan untuk } \\
\text { membuktikan } \\
\text { kebenaran hipotesis }\end{array}$ \\
\hline $\begin{array}{l}\text { Generalization } \\
\text { (Menarik }\end{array}$ & $\begin{array}{l}\text { Menarik simpulan } \\
\text { simpulan jawaban } \\
\text { atau penjelasan } \\
\text { ringkas }\end{array}$ \\
\hline
\end{tabular}

Pembelajaran inkuiri dirancang untuk mengajak peserta didik secara langsung ke dalam proses ilmiah dalam waktu yang singkat. Implementasi model pembelajaran inkuiri terbimbing (guided inquiry) menekankan pada aktivitas peserta didik secara maksimal untuk melatih keterampilan berpikir kritis. Model pembelajaran inkuiri terbimbing merupakan pembelajaran yang terpusat pada peserta didik.

Model pembelajaran inkuiri memiliki keunggulan karena siswa akan memiliki melakukan penelitian berulangulang dengan bimbingan dari guru, model ini melatih siswa untuk memiliki kemandirian belajar dalam mengumpulkan data dari suatu peristiwa dan mengolahnya secara logis (Sanjaya, 2006). Model pembelajaran inkuiri memberikan kesempatan kepada siswa untuk mengembangkan potensi intelektualnya serta siswa didorong untuk bertindak aktif mencari jawaban serta menarik kesimpulan atas masalah yang dihadapinya melalui proses berpikir ilmiah yang kritis, logis, dan sistematis (Sukriyanto, 2014).

Hasil penelitian Schlenker, dalam Joyce dan Weil (1992: 198), menunjukkan bahwa latihan inkuiri dapat meningkatkan pemahaman sains, produktif dalam berfikir kreatif, dan peserta didik menjadi terampil dalam memperoleh dan menganalisis informasi.

Pembrelajaran inkuiri terbimbing yang mempunyai ciri berpikir kritis ini diharapkan memotivasi siswa untuk bisa selalu mengambil inisitif pemecahan masalah dalam proses belajarnya. 


\section{METODE PENELITIAN}

Penelitian Tindakan Kelas ini dilaksanakan di kelas VII A MTs Negeri Batang. Jumlah keseluruhan peserta di kelas VII A adalah 36 anak. Rinciannya, peserta didik perempuan ada 22 anak, peserta didik laki-laki ada 14 anak.

Penelitian ini dilaksanakan dalam bentuk proses pengkajian berdaur 4 tahap, yaitu (1) merencanakan, (2) melakukan tindakan, (3) mengamati (observasi), dan (4) merefleksi.

Penelitian ini dilakukan sebanyak dua siklus. Setiap siklus dilakukan tiga pertemuan. Penelitian ini dilakukan kurang lebih selama tiga bulan (termasuk di dalamnya pembuatan proposal sampai pembuatan laporan). Hasil yang diharapkan setiap siklus adalah adanya perubahan perilaku peserta didik berupa motivasi belajar yang meningkat dan kompetensi akademis (hasil belajar) yang meningkat.

Penelitian Tindakan Kelas ini menggunakan metode Observasi, dan Tes dalam perolehan data hasil penelitian. Metode observasi ini digunakan untuk memperoleh data tentang proses pelaksanaan tindakan yang menggunakan model Pembelajaran Inquiri Terbimbing (Guided Inquiri). Pelaksanaan observasi ini, peneliti dibantu oleh 3 (tiga) teman sejawat dengan maksud agar proses pembelajaran bisa direkam sedetail mungkin dari aspek langkah-langkah pembelajaran, perilaku guru dan peserta didik. Untuk melakukan observasi peneliti menggunakan lembar observasi untuk mengetahui kegiatan guru dan lembar observasi untuk mengetahui kegiatan peserta didik.

Data kuantitatif yang diperoleh dari hasil ulangan akhir siklus diolah dengan menggunakan deskripsi persentase. Nilai yang diperoleh peserta didik dirata-rata untuk menemukan tingkat pemahaman para peserta didik dalam pembelajaran Matematika. Selanjutnya, pengkategorian pencapaian hasil belajar peserta didik dipakai dengan standar (a) belum tuntas $(\mathrm{N}<\mathrm{KKM})$, (b) tuntas ( $\mathrm{N}=\mathrm{KKM})$, dan (c) melampaui $(\mathrm{N}>\mathrm{KKM})$. Lalu dihitung berapa jumlah peserta didik yang mendapat nilai belum tuntas, tuntas dan melampaui. Setelah diketahui jumlah masing-masing, lalu diprosentase dengan cara membagi dengan jumlah peserta didik dikalikan 100\%. Maka akan didapatkan jumlah persentase peserta didik yang mendapat nilai (a) belum tuntas, (b) tuntas, dan (c) melampaui.

Indikator kinerja dari data kuantitatif, berupa hasil belajar peserta didik selama mengikuti pembelajaran. Tindakan perbaikan ini dikatakan berhasil ditandai dengan: (a) nilai hasil belajar dari siklus ke siklus mengalami kenaikan, (b) pengkategorian pencapaian hasil belajar peserta didik dipakai dengan standar (a) belum tuntas ( $\mathrm{N}<\mathrm{KKM})$, (b) tuntas (N=KKM), dan (c) melampaui (N>KKM). PTK dikatakan berhasil jika $100 \%$ peserta didik mencapai KKM atau melampaui KKM.

Indikator keberhasilan juga ditunjukkan oleh data kualitatif yang berupa kegiatan guru dan perilaku peserta didik yakni motivasi peserta didik yang semakin meningkat di setiap siklusnya. Motivasi peserta didik dikategorikan dalam (1) rendah, (2) sedang, dan (3) tinggi. Kategori tersebut berdasarkan hasil observasi motivasi siswa dalam pembelajaran dimana kategori rendah apabila skor observasi siswa antara 0 sampai 3, kategori sedang apabila skor observasi siswa antara 4 sampai 7 dan kategori tinggi apabila skor observasi siswa antara 8 sampai 10. Tindakan dikatakan berhasil jika setidaknya persentase peserta didik yang motivasi belajar rendah sudah mencapai $0 \%$.

Berdasarkan penjelasan tersebut di atas, maka hipotesis tindakan PTK ini adalah sebagai berikut: "Model pembelajaran Inkuiri Terbimbing (Guided Inquiri) dapat meningkatkan motivasi dan hasil belajar peserta didik pada Mata Pelajaran IPA Kelas VII Semester Gasal Tahun Pelajaran 2019/2020 MTsN Batang akan meningkat". 


\section{HASIL PENELITIAN DAN PEMBAHASAN}

\section{Hasil Penelitian}

\section{Siklus 1}

Rencana tindakan pada siklus 1 untuk memperbaiki motivasi dan hasil belajar peserta didik dibuat Rencana Pelaksanaan Pembelajaran (RPP) untuk tiga kali pertemuan (RPP lengkap terlampir). RPP dikembangkan dengan menggunakan model pembelajaran Inkuiri Terbimbing (Guided Inquri) sesuai dengan langkah-langkah yang dibahas dalam kajian teori. Kompetensi Dasar yang akan diajarkan dalam RPP ini adalah KD Klasifikasi Makhluk Hidup.

Berdasarkan hasil observasi yang dilakukan oleh tiga observer (teman sejawat), dengan menggunakan lembar observasi dalam tiga kali pertemuan, yakni pertemuan pertama hari Jum'at tanggal 23 Agustus 2019, pertemuan kedua hari Senin tanggal 26 Agustus 2019, dan pertemuan ketiga hari Jum'at tanggal 30 Agustus 2019, ditemukan bahwa proses pembelajaran berlangsung sebagai berikut;

\section{1) Pertemuan pertama}

Secara umum sudah sesuai dengan rencana tindakan (RPP pertemuan 1). Berdasarkan observasi dan hasil analisis data diketahui bahwa ada beberapa langkah pembelajaran yang tidak dilakukan secara optimal, yakni sebagai berikut; a) Pembimbingan pada peserta didik dalam melakukan percobaan harus lebih baik b) Pemberian umpan balik pada peserta didik harus diperbaiki c) Pemberian tugas mandiri yang harus sesuai waktu.

Adapun hasil dari kegiatan refleksi itu adalah sebagai berikut : a) Guru (peneliti) harus memberikan pembimbingan dalam melakukan percobaan atau pengamatan serinci mungkin, supaya peserta didik lebih maksimal dalam mengumpulkan data; b) Guru (peneliti) harus memperbaiki cara memberikan umpan balik, yakni dengan cara menunjukkan secara detail kesalahan-kesalahan yang dilakukan peserta didik beserta solusinya, seraya memberikan motivasi bahwa kesalahan bukanlah cela, tetapi sebagai cara untuk memotivasi diri untuk belajar kembali; c) Guru (peneliti) harus bisa memberikan tugas yang menantang sekaligus tidak membuat peserta didik putus asa. Caranya adalah tugas yang diberikan dari yang ringan sampai yang sulit, tetapi masih bisa melakukan yang mudah sehingga tidak membuat peserta didik putus asa; d) Guru (peneliti) secara umum harus mengoptimalkan langkah tindakan yang mendapat skor Baik (2). Tingkatkan ke yang Sangat Baik (3).

\section{2) Pertemuan kedua}

Secara umum sudah sesuai dengan rencana tindakan (RPP pertemuan kedua). Berdasarkan observasi dan hasil analisis data diketahui bahwa ada beberapa langkah pembelajaran yang tidak dilakukan secara optimal, yakni sebagai berikut: a) Pembimbingan pada peserta didik dalam melakukan percobaan harus lebih baik; b) Pemberian umpan balik pada peserta didik harus diperbaiki; c) Pemberian tugas mandiri yang harus sesuai waktu

Adapun hasil dari kegiatan refleksi itu adalah sebagai berikut : a) Guru (peneliti) harus memberikan pembimbingan dalam melakukan percobaan atau pengamatan serinci mungkin, supaya peserta didik lebih maksimal dalam mengumpulkan data b) Guru (peneliti) harus memperbaiki cara memberikan umpan balik, yakni dengan cara menunjukkan secara detail kesalahan-kesalahan yang dilakukan peserta didik beserta solusinya, seraya memberikan motivasi bahwa kesalahan bukanlah cela, tetapi sebagai cara untuk memotivasi diri untuk belajar kembali c) Guru (peneliti) harus bisa memberikan tugas yang menantang sekaligus tidak membuat peserta didik putus asa. Caranya adalah tugas yang diberikan dari yang ringan sampai yang sulit, tetapi masih bisa melakukan yang mudah sehingga tidak membuat peserta didik putus asa. 


\section{3) Pertemuan ketiga}

Secara umum sudah sesuai dengan rencana tindakan (RPP pertemuan ketiga). Pada pertemuan ketiga ini masih sama dengan pada pertemuan pertama dan kedua. Kekurangannya juga relatif masih sama dengan pada pertemuan satu dan dua.

Menurut observer 1 didapatkan data bahwa, persentase peserta didik yang memiliki motivasi belajar rendah $16,67 \%$, sedang 45,37\%, dan tinggi $37,96 \%$. Menurut observer 2 didapatkan data bahwa persentase peserta didik yang memiliki motivasi rendah ada 18,52\%, sedang 37,96\%, dan tinggi 43,52\%. Menurut observer 3 didapatkan data bahwa persentase peserta didik yang motivasi rendah ada $18,52 \%$, sedang $43,37 \%$ dan tinggi $36,11 \%$. Jika diratarata dari tiga observer tersebut diperoleh data bahwa persentase peserta didik yang motivasi belajarnya rendah ada $17,90 \%$, sedang 42,90\% dan tinggi 39,20\%. Jika dibandingkan dengan motivasi peserta didik pada kondisi awal adalah sebagai berikut :

Tabel 1. Motivasi Peserta Didik

\begin{tabular}{cccc}
\hline No & $\begin{array}{c}\text { Kategori } \\
\text { Keaktifan }\end{array}$ & $\begin{array}{c}\text { Kondisi } \\
\text { awal }\end{array}$ & Siklus 1 \\
\hline 1 & Tinggi & $10 \%$ & $39,20 \%$ \\
2 & Sedang & $50 \%$ & $42,90 \%$ \\
3 & Rendah & $40 \%$ & $17,90 \%$ \\
\hline
\end{tabular}

Tabel di atas menunjukkan bahwa motivasi belajar peserta didik pada siklus 1 mengalami peningkatan. Tetapi PTK belum dikatakan berhasil, karena indikator yang ditetapkan adalah jika persentase peserta didik yang motivasi belajar dengan kategori rendah mencapai $0 \%$. Dari tiga observer menunjukkan bahwa pembelajaran secara umum sudah bagus, tetapi harus ada beberapa yang harus diperbaiki: a) Pembimbingan pada peserta didik dalam melakukan percobaan harus lebih baik b) Pemberian umpan balik pada peserta didik harus diperbaiki c) Pemberian tugas mandiri yang harus sesuai waktu

Berdasarkan tes yang dilakukan di akhir siklus 1 diketahui bahwa rata-rata nilai yang diperoleh peserta didik untuk mapel IPA KD.2 (KKM 70) adalah 62,78. Jika dipersentase berdasarkan kategori belum tuntas $(<\mathrm{KKM})$, tuntas $(=\mathrm{KKM})$, dan melampaui ( $>\mathrm{KKM})$ adalah sebagai berikut :

Tabel 2. Hasil belajar peserta didik

\begin{tabular}{|c|c|c|c|}
\hline No & Kategori Nilai & $\begin{array}{c}\text { Kondisi } \\
\text { awal }\end{array}$ & $\begin{array}{c}\text { Siklus } \\
1 \\
\end{array}$ \\
\hline 1 & $\begin{array}{l}\text { Belum Tuntas } \\
(<\text { KKM })\end{array}$ & $66,25 \%$ & $50 \%$ \\
\hline 2 & Tuntas $\quad(=\mathrm{KKM})$ & $23,75 \%$ & $25 \%$ \\
\hline 3 & Melampaui (>KKM) & $10 \%$ & $25 \%$ \\
\hline
\end{tabular}

Tabel di atas menunjukkan bahwa hasil belajar peserta didik mengalami peningkatan setelah dilakukan tindakan. Persentase peserta didik yang belum tuntas mengalami penurunan dari kondisi awal ke siklus 1 ( dari 66,25\% menjadi 50\%). Persentase peserta didik yang sudah tuntas mengalami kenaikan dari kondisi awal ke siklus 1 (dari 23,75\% menjadi $25 \%$ ). Persentase peserta didik yang melampaui juga mengalami kenaikan dari $10 \%$ menjadi $25 \%$.

Indikator keberhasilan dari PTK ini adalah, PTK dikatakan sudah berhasil jika persentase peserta didik yang nilai hasil belajarnya sudah tuntas mencapai minimal 80\%. Dari tabel menunjukkan bahwa persentase peserta didik yang nilainya tuntas dan melampaui baru mencapai 50\% ( nilai tuntas $25 \%$ dan nilai melampaui 25\%), maka PTK harus dilanjutkan pada siklus 2 .

Setelah mengkaji proses pembelajaran yang dilakukan pada siklus 1, bagaimana hasil belajar peserta didik, dan bagaimana motivasi peserta didik, peneliti melakukan refleksi. Kegiatan ini dibantu teman sejawat. Tujuannya adalah untuk melakukan solusi perbaikan yang dapat dilakukan pada siklus 2. Adapun hasil dari kegiatan refleksi itu adalah sebagai berikut; a) Guru (peneliti) harus memberikan pembimbingan dalam melakukan percobaan atau pengamatan serinci mungkin, supaya peserta didik lebih maksimal dalam mengumpulkan data; b) Guru (peneliti) harus memperbaiki cara memberikan umpan 
balik, yakni dengan cara menunjukkan secara detail kesalahan-kesalahan yang dilakukan peserta didik beserta solusinya, seraya memberikan motivasi bahwa kesalahan bukanlah cela, tetapi sebagai cara untuk memotivasi diri untuk belajar kembali; c) Guru (peneliti) harus bisa memberikan tugas yang menantang sekaligus tidak membuat peserta didik putus asa. Caranya adalah tugas yang diberikan dari yang ringan sampai yang sulit, tetapi masih bisa melakukan yang mudah sehingga tidak membuat peserta didik putus asa; d)Guru (peneliti) secara umum harus mengptimalkan langkahlangkah tindakan yang mendapat skor Baik (2). Tingkatkan ke yang Sangat Baik (3).

\section{Siklus 2}

Rencana tindakan pada siklus 2 untuk memperbaiki motivasi dan hasil belajar peserta didik dibuat Rencana Pembelajaran (RPP) untuk tiga kali pertemuan (RPP lengkap terlampir). RPP dikembangkan dengan menggunakan model pembelajaran Inkuiri Terbimbing (Guided Inquiri) sesuai dengan langkahlangkah yang dibahas dalam kajian teori. Kompetensi Dasar yang akan diajarkan dalam RPP ini adalah KD Klasifikasi Makhluk Hidup.

Secara umum langkah-langkah pembelajaran pada siklus 2 ini sama dengan pada siklus 1. Perbedaannya adalah pada tindakan yaitu pada setiap langkah dioptimalkan sesuai hasil refleksi pada siklus 1. Yang diperbaiki adalah sebagai berikut : 1) Guru (peneliti) harus memberikan pembimbingan dalam melakukan percobaan atau pengamatan serinci mungkin, supaya peserta didik lebih maksimal dalam mengumpulkan data; 2) Guru (peneliti) harus memperbaiki cara memberikan umpan balik, yakni dengan cara menunjukkan secara detail kesalahan-kesalahan yang dilakukan peserta didik beserta solusinya, seraya memberikan motivasi bahwa kesalahan bukanlah cela, tetapi sebagai cara untuk memotivasi diri untuk belajar kembali; 3) Guru (peneliti) harus bisa memberikan tugas yang menantang sekaligus tidak membuat peserta didik putus asa. Caranya adalah tugas yang diberikan dari yang ringan sampai yang sulit, tetapi masih bisa melakukan yang mudah sehingga tidak membuat peserta didik putus asa; 4) Guru (peneliti) secara umum harus mengoptimalkan langkahlangkah tindakan yang mendapat skor Baik (2). Tingkatkan ke yang Sangat Baik (3).

Berdasarkan hasil observasi yang dilakukan oleh tiga observer (teman sejawat), dengan menggunakan lembar observasi (terlampir) dalam tiga kali pertemuan, yakni pertemuan pertama hari Senin tanggal 2 September tahun 2019. Pertemuan kedua pada hari Jum'at tangggal 5 September tahun 2019. Pertemuan ketiga pada hari Senin tanggal 9 September tahun 2019, ditemukan bahwa proses pembelajaran berlangsung sebagai berikut:

Tabel 4. Hasil belajar peserta didik

\begin{tabular}{|c|c|c|c|c|}
\hline No & $\begin{array}{c}\text { Kategori } \\
\text { Nilai }\end{array}$ & $\begin{array}{c}\begin{array}{c}\text { Kondisi } \\
\text { awal }\end{array} \\
\end{array}$ & $\begin{array}{c}\text { Siklus } \\
1 \\
\end{array}$ & $\begin{array}{c}\text { Siklus } \\
2 \\
\end{array}$ \\
\hline 1 & $\begin{array}{l}\text { Belum Tuntas } \\
\qquad<\mathrm{KKM})\end{array}$ & $66,25 \%$ & $50 \%$ & $8,33 \%$ \\
\hline 2 & $\begin{array}{l}\text { Tuntas } \\
\text { (= KKM) }\end{array}$ & $23,75 \%$ & $25 \%$ & $19,45 \%$ \\
\hline 3 & $\begin{array}{l}\text { Melampaui } \\
(>\mathrm{KKM})\end{array}$ & $10 \%$ & $25 \%$ & $72,22 \%$ \\
\hline
\end{tabular}

Tabel di atas menunjukkan bahwa hasil belajar peserta didik mengalami peningkatan setelah dilakukan tindakan. Persentase peserta didik yang belum tuntas mengalami penurunan dari kondisi siklus 1 ke siklus 2 ( dari 50\% menjadi 8,33\%). Persentase peserta didik yang sudah tuntas mengalami penurunan dari siklus 1 ke siklus 2 (dari 25\% menjadi $19,45 \%$ ). Sedangkan persentase peserta didik yang melampaui mengalami kenaikan yang cukup berarti yaitu dari $25 \%$ menjadi $72,22 \%$. Jadi persentase peserta didik yang tuntas serta melampaui adalah $91,67 \%$ ( peserta didik tuntas $19,45 \%$ dan melampaui $72,22 \%$ ).

Indikator keberhasilan dari PTK ini adalah, PTK dikatakan sudah berhasil jika persentase peserta didik yang nilai hasil 
belajarnya sudah tuntas mencapai minimal $80 \%$. Dari tabel menunjukkan bahwa persentase peserta didik yang nilainya tuntas dan melampaui sudah mencapai 91,67\%, maka PTK sudah berhasil.

Hasil analisis data menunjukkan proses pembelajaran yang dilakukan pada siklus 2 jauh lebih baik dibanding pada siklus 1. Secara umum proses pembelajaran pada siklus 2 kategorinya sangat bagus. Dari data-data tersebut menunjukkan bahwa tindakan yang dilakukan oleh guru (peneliti) terus mengalami perbaikan dan sudah mencapai sesuai yang ditargetkan. Maka siklus PTK ini sekesai pada siklus 2 saja.

\section{Pembahasan}

Tahap-tahap belajar Inquiri Terbimbing (Guided Inquiri) menunjukkan proses pembelajaran (kegiatan) yang bervariasi. Secara umum langkah-langkah tersebut dapat memberikan dampak terhadap peningkatan motivasi dan hasil belajar peserta didik. Tetapi, hasil penelitian ini menunjukkan bahwa setiap langkah pembelajaran harus dilakukan lebih kreatif dan inovatif. Artinya guru memiliki peran sentral. Guru harus bisa merancang secara kreatif pada setiap langkah model pembelajaran Inquiri Terbimbing ini. Hal ini dapat dilihat sebagai berikut :

\section{Siklus pertama}

Pada siklus ini guru telah menerapkan langkah-langkah model Inquiri Terbimbing (Guided Inquiri) sesuai dengan prosedur. Tetapi pad pelaksaannya belum optimal karena ada beberapa langkah yang dilakukan memerlukan kreatifitas dan inovasi, yakni menggunakan media pembelajaran berupa berbagai macam gambar makhluk hidup yang digunakan untuk melatih peserta didik berpikir kritis melakukan pengamatan dalam mengklasifikasikan makhluk hidup berdasarkan ciri-ciri yang diamati. Tetapi secara umum, pada siklus ini hasilnya lebih baik dibanding dengan kondisi awal dari aspek motivasi dan hasil belajar peserta didik.

Setelah dilakukan diskusi refleksi, kekurangan-kekurangan tersebut diperbaiki, yakni dengan (1) Guru (peneliti) harus memberikan pembimbingan dalam melakukan percobaan atau pengamatan serinci mungkin, supaya peserta didik lebih maksimal dalam mengumpulkan data. (2) Guru (peneliti) harus memperbaiki cara memberikan umpan balik, yakni dengan cara menunjukkan secara detail kesalahan-kesalahan yang dilakukan peserta didik beserta solusinya, seraya memberikan motivasi bahwa kesalahan bukanlah cela, tetapi sebagai cara untuk memotivasi diri untuk belajar kembali. (3) Guru (peneliti) harus bisa memberikan tugas yang menantang sekaligus tidak membuat peserta didik putus asa. Caranya adalah tugas yang diberikan dari yang ringan sampai yang sulit, tetapi masih bisa melakukan yang mudah sehingga tidak membuat peserta didik putus asa. (4) Guru (peneliti) secara umum harus mengptimalkan langkahlangkah tindakan yang mendapat skor Baik (2). Tingkatkan ke yang Sangat Baik (3). 


\section{Siklus kedua}

Dari analisis data hasil belajar peserta didik menunjukkan dari kondisi awal, ke siklus 1 dan siklus 2 mengalami peningkatan yang cukup berarti. Persentase hasil belajar pada siklus 2 sudah mencapai target (indikator kinerja) bahkan melebihi. Hal ini sesuai dengan penelitian Erlin (2016) bahwa hasil belajar peserta didik mengalami peningkatan dari $62,32 \%$ pada siklus pertama menjadi $84,28 \%$ pada siklus kedua. Dengan demikian dapat dikatakan bahwa hasil belajar peserta didik mengalami peningkatan dengan diterapkannya pembelajaran inkuiri.

Data ini menunjukkan bahwa proses pembelajaran yang dilakukan oleh guru (peneliti) memberikan dampak bagi peningkatan terhadap hasil belajar peserta didik. Untuk lebih jelasnya dapat dilihat pada tabel dan grafik berikut ini :

Tabel 5. Hasil Belajar Peserta Didik

\begin{tabular}{llccc}
\hline No & $\begin{array}{c}\text { Kategori } \\
\text { Nilai }\end{array}$ & $\begin{array}{c}\text { Kondisi } \\
\text { awal }\end{array}$ & $\begin{array}{c}\text { Siklus } \\
\mathbf{1}\end{array}$ & $\begin{array}{c}\text { Siklus } \\
\mathbf{2}\end{array}$ \\
\hline 1 & $\begin{array}{l}\text { Belum } \\
\text { Tuntas } \\
(<\text { KKM })\end{array}$ & $66,25 \%$ & $50 \%$ & $8,33 \%$ \\
2 & $\begin{array}{l}\text { Tuntas } \\
(=\text { KKM) } \\
3\end{array}$ & $23,75 \%$ & $25 \%$ & $19,45 \%$ \\
& $\begin{array}{l}\text { Melampaui } \\
(>\text { KKM })\end{array}$ & $10 \%$ & $25 \%$ & $72,22 \%$ \\
\hline
\end{tabular}

Grafik 1. Hasil belajar peserta didik

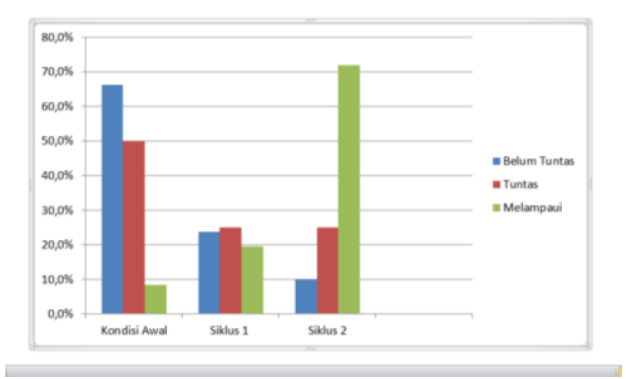

Analisis data motivasi belajar peserta didik menunjukkan kondisi awal, siklus 1 dan siklus 2 mengalami peningkatan yang cukup berarti. Pada siklus 2 persentase peserta didik yang motivasi rendah sudah mencapai $0 \%$. Jadi sudah mencapai target seperti yang ditetapkan pada indikator kinerja PTK ini. Untuk lebih jelasnya dapat dilihat pada tabel dan grafik dibawah ini.

Tabel 6. Hasil observasi motivasi peserta didik

\begin{tabular}{lllll}
\hline No & Kategori & Kondisi & Siklus & Siklus \\
& Keaktifan & awal & 1 & 2 \\
\hline 1 & Tinggi & $10 \%$ & $39,20 \%$ & $86,31 \%$ \\
2 & Sedang & $50 \%$ & $42,90 \%$ & $13,58 \%$ \\
3 & Rendah & $40 \%$ & $17,90 \%$ & $0 \%$ \\
\hline
\end{tabular}

Grafik 2. Hasil observasi motivasi peserta didik

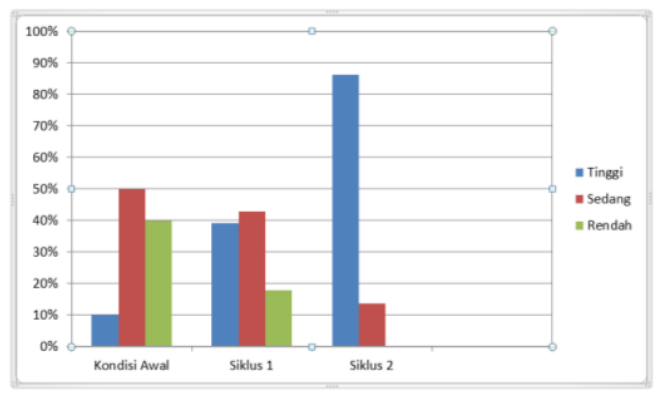

Analisis data menunjukkan proses pembelajaran yang dilakukan pada siklus 2 jauh lebih baik dibanding pada siklus 1 . Penerapan model Pembelajaran inkuiri yang dilakukan oleh guru menyebabkan hasil belajar dan motivasi siswa meningkat. Hal ini sejalan dengan penelitian yang dilakukan oleh Agustanti (2012) yaitu implementasi metode inkuiri dapat meningkatkan hasil belajar Biologi. Hasil belajar mengalami peningkatan karena peserta didik melakukan pembelajaran dengan antusias dan interaksi yang baik antara guru dan peserta didik, mereka melakukan kerja kelompok dan berpartisipasi aktif dalam pembelajaran.

Secara umum proses pembelajaran pada siklus 2 kategorinya sangat bagus. Dari data-data tersebut menunjukkan bahwa tindakan yang dilakukan oleh guru (peneliti) terus mengalami perbaikan dan sudah mencapai sesuai yang ditargetkan. Maka siklus PTK ini selesai pada siklus 2 saja 


\section{PENUTUP}

\section{Simpulan}

Simpulan penelitian ini adalah (1) Proses pembelajaran dengan menggunakan model pembelajaran Inquiri Terbimbing (Guided Inquiri) adalah sebagai berikut : Tahap 1 : Mengajukan pertanyaan, Tahap 2: Merumuskan hipotesis, Tahap 3: Merancang dan Melakukan pengamatan, Tahap 4: Mengumpulkan data, Tahap 5: Analisis data, Tahap 6: Membuat kesimpulan. Pelaksanaannya dari siklus 1 ke siklus 2 mengalami perbaikan. (2) Penelitian ini menunjukkan bahwa motivasi belajar dari kondisi awal, siklus 1 dan siklus 2 terus mengalami peningkatan. Pada kondisi awal ke siklus 1 dan ke siklus 2 persentase peserta didik yang motivasi dengan kategori rendah terus mengalami penurunan, yakni $40 \%$ $17,90 \% \quad-\quad 0 \%$. Sedangkan yang kategorinya sedang dari 50\% - 42,90\% $13,58 \%$. Dan yang kategorinya tinggi dari 10\% - 39,20\% - 86,31\%. (3) Penelitian ini menunjukkan bahwa hasil belajar peserta didik mengalami peningkatan setelah dilakukan tindakan. Persentase peserta didik yang belum tuntas mengalami penurunan dari siklus 1 ke siklus 2 dari $50 \%$ menjadi $8,33 \%$. Persentase peserta didik yang tuntas dari $25 \%$ menjadi $19,45 \%$ dan persentase peserta didik yang melampaui KKM dari siklus 1 ke siklus 2 mengalami peningkatan yang cukup berarti dari 25\% menjadi 72,22\%. Persentase peserta didik yang tuntas dan melampaui menjadi 91,67\%. Indikator keberhasilan PTK ini adalah, bahwa PTK ini dikatakan berhasil jika persentase peserta didik $100 \%$ mencapai nilai diatas KKM 72 atau setidaknya peserta didik mencapai nilai sama dengan KKM. Hasil penelitian menunjukkan bahwa persentase peserta didik yang nilainya tuntas dan mencapai sama dengan KKM mencapai $100 \%$ maka PTK ini sudah berhasil.

\section{Saran}

Hasil penelitian yang diperoleh dari uraian sebelumnya agar proses belajar mengajar IPA lebih efektif dan lebih memberikan hasil yang optimal bagi peserta didik, maka perlu diterapkan model pembelajaran Inkuiri Terbimbing (Guided Inquiri). Untuk melaksanakan pembelajaran dengan model pembelajaran Inquiri Terbimbing (Guided Inquiri) harus memberikan pembimbingan dalam melakukan percobaan atau pengamatan serinci mungkin, supaya peserta didik lebih maksimal dalam mengumpulkan data. Selain itu peserta didik harus diberikan tugas yang menantang dari yang ringan sampai yang sulit untuk melatih peserta didik berfikir kritis, sehingga peserta didik nantinya dapat menemukan pengetahuan baru, memperoleh konsep dan keterampilan, sehingga peserta didik berhasil atau mampu memecahkan masalah-masalah yang dihadapinya.

\section{DAFTAR PUSTAKA}

Abdurrahman, Mulyana. 2003. Pendidikan bagi anak berkesulitan belajar. Rineka Cipta: Jakarta

Agustanti. 2012. Implementasi Metode Inkuiri untuk Meningkatkan Hasil Belajar Biologi. Jurnal Pendidikan, 2 (2): 16-20.

Erlin. 2016. Peningkatan Motivasi dan Hasil Belajar Siswa Melalui Model Pembelajaran Inkuiri pada Siswa SMA. Jurnal Pendidikan : Teori, Penelitian dan Pengembangan. Volume: I Nomor: 10 Bulan: Oktober. Halaman: 2047-2049

Sanjaya, W. 2006. Strategi Pembelajaran Berorientasi Standar Proses Pendidikan. Jakarta: Kencana Prenada Media.

Sardiman, A.M. 2011. Interaksi dan Motivasi Belajar. Jakarta : Rajawali Press 
Sudjana, Nana. 2011. Cara Belajar Siswa Aktif-Dalam Proses Belajar Mengajar. Bandung:Sinar Baru.

Sudjana, Nana. 2004. Dasar-Dasar Proses Belajar Mengajar. Bandung: Sinar Baru Algensindo

Sukriyanto, dkk. 2014. Penerapan Model Inkuiri dalam Meningkatkan Aktivitas dan Hasil Belajar Siswa Mata Pelajaran IPS Pokok Bahasan Akibat Perilaku Manusia terhadap Lingkungan di Kelas IV SDN 1 Bayeman Arjasa Situbondo Tahun 2012/2013. Jurnal Pendidikan 1(1):3234 .

Trianto, Ibnu Badar. 2015. Medesain Model Pembelajaran Inovatif, Progresif, dan Kontekstual : Konsep, Landasan, dan Implementasi pada Kurikulum 2013 (Kurikulum Tematik Integratif/TKI). Jakarta : Prenadamedia Group.

W.S. Winkel. 1996, Psikologi Pengajaran. Jakarta: Grasindo. 